\title{
Geologia da Humanidade por Paul Crutzen
}

doi https://doi.org/10.21814/anthropocenica.3096

Durante os últimos três séculos, os efeitos dos seres humanos no ambiente global escalaram. Por causa destas emissões antropogénicas de dióxido de carbono, o clima global pode afastar-se significativamente do comportamento natural por muitos milénios vindouros. Parece apropriado atribuir o termo "Antropoceno" à presente, de muitas formas dominada pelo homem, época geológica, complementando o Holoceno - o quente período dos últimos 10-12 milénios. O Antropoceno pode dizer-se que começou na parte final do século dezoito, quando análises do ar preso no gelo polar mostraram o início do crescimento global de concentrações de dióxido de carbono e metano. Esta data também se dá o caso de coincidir com o projeto de máquina vapor de James Watt em 1784.

A crescente influência da humanidade no ambiente foi reconhecida desde pelo menos 1873, quando o geólogo italiano Antonio Stoppani falou de uma "nova força telúrica que, em poder e universalidade, pode ser comparada às maiores forças da Terra", referindo-se à "era antropozoica”. E em 1926, V. I. Vernadsky reconheceu o crescente impacto da humanidade: "A direção na qual os processos de evolução devem seguir, nomeadamente no sentido de aumentar consciência e pensamento, e formas que tenham cada vez mais influência na sua envolvente". Teilhard de Chardin e Vernadsky usaram o termo "noosfera" - "mundo do pensamento" - para assinalar o crescimento do papel do poder cerebral humano na formação do seu próprio futuro e ambiente.

A rápida expansão da humanidade em números e exploração per capita dos recursos da Terra tem continuado a um ritmo acelerado. Durante os últimos três séculos, a população humana aumentou dez vezes para mais de 6 mil milhões e espera-se que atinja 10 mil milhões neste século. A população bovina produtora de metano subiu para 1,4 mil milhões. Cerca de 30-50\% da superfície terrestre do planeta é explorada por humanos. Florestas tropicais desaparecem a um ritmo acelerado, libertando dióxido de carbono e
João Ribeiro

Mendes

Departamento de Filosofia,

Universidade do Minho

Institute for Anthropocene

Studies

Portugal

\icrmendes@ilch.uminho.pt

(iD) $0000-0003-3731-2246$

\section{C.}




\section{Geologia da Humanidade}

aumentando fortemente a extinção de espécies. A construção de barragens e o desvio de rios tornou-se comum. Mais de metade de toda a água fresca acessível é utilizada pela humanidade. As pescas removem mais de $25 \%$ da produção primária em regiões oceânicas de afloramento e 35\% nas regiões temperadas da plataforma continental. O uso de energia cresceu 16 vezes durante o século vinte, causando 160 milhões de toneladas de emissões de dióxido de enxofre atmosférico por ano, mais do dobro da soma das suas emissões naturais. Mais nitrogénio fertilizante é aplicado na agricultura do que o fixado naturalmente em todos os ecossistemas terrestres; a produção de óxido nítrico pela queima de combustível fóssil e a biomassa também se sobrepõe às emissões naturais. A queima de combustíveis fósseis e a agricultura têm causado aumentos substanciais nas concentrações de gases de "efeito de estufa" - dióxido de carbono em 30\% e metano em mais de $100 \%$ - atingindo os seus níveis mais altos ao longo dos últimos 400 milénios, seguindo-se mais.

Até agora, estes efeitos têm sido em grande parte causados por apenas $25 \%$ da população mundial. As consequências são, entre outras, precipitação ácida, "smog" fotoquímico e aquecimento climático. Portanto, de acordo com as últimas estimativas da Painel Intergovernamental sobre Mudanças Climáticas (IPCC), a Terra aquecerá entre $1,4-5,8^{\circ} \mathrm{C}$ durante este século.

Muitas substâncias tóxicas são libertadas no ambiente, mesmo algumas que não são tóxicas, mas que, ainda assim, têm severos efeitos nocivos, por exemplo, os clorofluorcarbonos que causaram o "buraco de ozono" da Antárctica (e que agora estão regulados). As coisas poderiam ter ficado muito piores: as propriedades de destruição da camada de ozono pelos halógenos têm sido estudadas desde meados da década de 1970. Se se tivesse revelado que o cloro se comportava quimicamente como o bromo, o buraco do ozono já teria sido um fenómeno global, durante todo o ano, não apenas um evento da primavera Antárctica. Mais por sorte do que por sabedoria, esta situação catastrófica não se processou.

A menos que ocorra uma catástrofe global - um impacto de meteorito, uma guerra mundial ou uma pandemia - a humanidade continuará a ser uma grande força ambiental durante muitos milénios. Uma tarefa assustadora têm por diante cientistas e engenheiros, de orientarem a sociedade para uma gestão ambiental sustentável durante a era do Antropoceno. Isto exigirá um comportamento humano adequado a todas as escalas, e pode muito bem envolver projetos de geoengenharia de grande escala, internacionalmente aceites, por exemplo, para “otimizar” o clima. Nesta fase, no entanto, ainda estamos em grande medida a pisar terra incógnita. 
Leitura adicional

Marsh, G. P. Man and Nature (1864). (Reimpresso como The Earth as Modified by Human Action (Belknap Press, Cambridge, Massachusetts, 1965)).

Crutzen, P. J. \& Stoermer, E. F. IGBP Newsletter 41 (Royal Swedish Academy of Sciences, Stockholm, 2000).

Clark, W. C. \& Munn, R. E. (eds) Sustainable Development of the Biosphere Cap. 1 (Cambridge Univ. Press, Cambridge, 1986).

Vernadski, V. I. The Biosphere (versão traduzida e anotada do original de 1926)

(Springer, New York, 1998).

Turner, B. L. et al. The Earth as Transformed by Human Action (Cambridge Univ. Press, Cambridge, 1990).

McNeill, J. R. Something New Under the Sun: An Environmental History of the TwentiethCentury World (W. W. Norton, New York, 2000).

Houghton, J. T. et al. (eds) Climate Change 2001: The Scientific Basis (Cambridge Univ. Press, Cambridge, 2001).

Berger, A. \& Loutre, M.-F. C. R. Acad. Sci. Paris 323 (IIA), 1-16 (1996).

Schellnhuber, H. J. Nature 402, C19-C23 (1999).

Fonte: Paul Crutzen (2002) Geology of Mankind. Nature, 415: 23

Para citar:

Mendes, J. (2020). Tradução do artigo “Geology of Mankind”, de Paul Crutzen e Eugene Stoermer. Anthropocenica. Revista de Estudos do Antropoceno e Ecocrítica 1: pp. 117-119. 